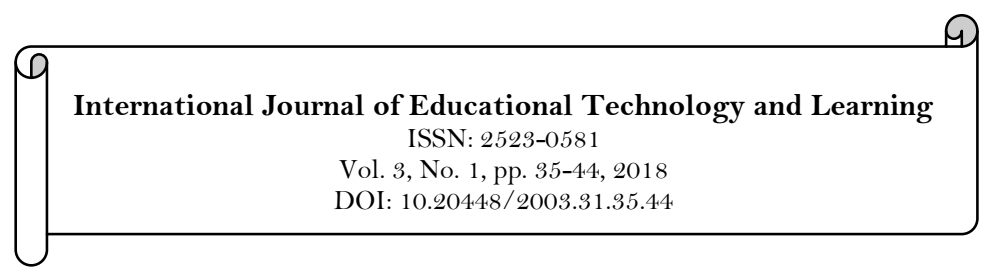

\title{
A Study of Language Learning Strategies for Practical Use through the Process of Cooperative Learning
}

\author{
Wannakarn Likitrattanaporn ${ }^{1}$ \\ ${ }^{1}$ Faculty of Humanities, Srinakharinwirot University, Bangkok, Thailand \\ Email:wannaka@g.swu.ac.th
}

\begin{tabular}{|c|c|}
\hline Abstract & \\
\hline $\begin{array}{l}\text { The purposes of this investigation were 1) to find out the average } \\
\text { students' use of language learning strategies 2) to examine the } \\
\text { students' opinions towards cooperative learning and 3) to investigate } \\
\text { the efficiency of the cooperative learning reflecting on the students' } \\
\text { practical use of language learning strategies. Research hypothesis of } \\
\text { this study is whether the students can gain and apply the knowledge } \\
\text { of how to use language learning strategies through their interaction, } \\
\text { exchanging information or ideas, brainstorming in cooperative } \\
\text { learning activity or not. The participants were } 79 \text { Thai } \\
\text { undergraduate students minoring in Linguistic Program at } \\
\text { Srinakharinwirot University, Bangkok, Thailand. The research } \\
\text { instruments were 1) Strategy Inventory for Language Learning } \\
\text { (SILL) Version } 7.0 \text { by Rebecca L. Oxford adapted by Park Bun-seon, } \\
\text { Kwon Mi-jeong and Hwang Jung-hwa in 1998 and } 2 \text { ) a } \\
\text { questionnaire designed to ask the students' opinions towards } \\
\text { cooperative learning. It was found out that } 49 \% \text { of the students } \\
\text { sometimes used language learning strategies, } 47 \% \text { of them usually } \\
\text { used language learning strategies and } 4 \% \text { of them generally not } \\
\text { used language learning strategies. It was discovered that the } \\
\text { students showed positive opinions towards cooperative learning. } \\
\text { Exchanging information through cooperative learning assists them } \\
\text { to gain more language learning strategies from peers that can be } \\
\text { applied to use in learning L2 later. }\end{array}$ & $\begin{array}{l}\text { Licensed: } \\
\text { This work is licensed under a } \\
\text { Creative Commons Attribution } \\
\text { 4.0 License. } \\
\text { Publisher: } \\
\text { Scientific Publishing Institute }\end{array}$ \\
\hline
\end{tabular}

\section{Introduction}

One of the major visions of the 21 st century educational management in Thailand at present is encouraging learners' long life learning. To conduct this learning style practically, teacher's spoon feeding or students' passive learning style must be changed. Teachers in Thailand should more emphasize on providing Thai students the opportunities to construct their knowledge by themselves. That means students should be coached to comprehend and criticize what they learn. Active learning by various paths such as learning-by-doing, problem solving-based, project-based, task-based, cooperative learning and the other like should be taken into consideration. My responsibility as an instructor is teaching the topic of language learning strategies in the course named; Language Acquisition at Srinakharinwirot University situated in Bangkok, Thailand. This topic has actually been investigated by many Thai researchers. They are interested in surveying the learners' frequency of using language learning strategies by using the wellknown instrument; Strategy Inventory for Language Learning strategies invented by Rebecca L. Oxford. Surveying the frequency of language learning strategies used by Thai students in the aspects of cognitive strategies, memory strategies, compensational strategies, metacognitive strategies, affective strategies and social strategies is insufficient for me. I consider that language learning strategies are very useful for Thai students who have to learn English as their L2. Thus I investigate Strategy Inventory for Language Learning (SILL) Version 7.0 by Rebecca (1998) and I discover that a student can find out by oneself on how often she or he uses language learning strategies from SILL adapted by Korean persons mentioned earlier. That means the student can realize whether she or he always or almost always used, usually used, sometimes used, generally not used and never or almost never used language learning strategies. Then I plan to use an adapted SILL by Park Bun-seon, Kwon Mi-jeong and Hwang Jung-hwa as an research instrument. My 
research question is if I provide an opportunity for the students to exchange their information of language learning strategies they used through the stages of cooperative learning, can it encourage the students to gain more ideas or information of using the strategies in the future or not. This question makes me to be interested in doing the research titled; A Study of Language Learning Strategies for Practical Use through the Process of Cooperative Learning.

\section{Theoretical Review}

\subsection{Definition of Language Learning Strategies}

Hardan (2013) refers to many experts who define the meaning of language learning strategies. O’Malley and Chamot in 1990 illustrated learning strategies as special thoughts or behaviours that individuals use to help them comprehend, learn, or retain new information. Cohen in 1990 stated that learning strategies are processes which are consciously selected by learners and which may result in actions taken to enhance the learning or use of a second or foreign language through the storage, retention, recall, and application of information about that language. Oxford in 1990 defined language learning strategies as specific actions taken by the learner to make learning easier, faster, more enjoyable, more self-directed, more effective, and more transferable to new situations.

Loganathan (2016) quote the definition of language learning strategies from Richards and Platt in 1992 who stated that learning strategies are intentional behavioural thoughts used by the learners during learning so as to better help them understand, learn, or remember new information.

It can be stated that language learning strategies are essential for students as they can help them learn or use a language more effectively. They are considered as a special way of processing information that improves comprehension, learning, or retention of the information.

\subsection{Oxford's Taxonomy of Language Learning Strategies}

There are 2 types of language learning strategies. They are direct strategies and indirect strategies. Direct strategies consist of memory strategies, cognitive strategies and compensational strategies whereas indirect strategies comprise metacognitive strategies, affective strategies and social strategies.

Memory strategies are contained in creating mental linkage, applying images and sounds, reviewing well and employing action.

Cognitive strategies involve practicing, receiving and sending messages strategies, analysing and reasoning and creating structure for input and output.

Compensational strategies include guessing intelligently and overcoming limitations in speaking and writing.

Metacognitive strategies are made up of centring your learning, arranging and planning your learning and evaluating your learning.

Affective strategies cover lowering your anxiety, encouraging yourself and taking your temperature. Social strategies are composed of asking questions, cooperating with others and empathizing with others.

Language learning strategies are categorized into six major groups. They are cognitive strategies, metacognitive strategies, memory-related strategies, compensatory strategies, social strategies and affective strategies. The details of these 6 strategies are explained as follows: (Oxford, 2003)

Cognitive strategies enable the learner to manipulate the language material in direct ways, e.g., through reasoning, analysis, note-taking, summarizing, synthesizing, outlining, reorganizing information to develop stronger schemas (knowledge structures), practicing in naturalistic settings, and practicing structures and sounds formally.

Metacognitive strategies are identifying one's own learning style preferences and needs, planning for an L2 task, gathering and organizing materials, arranging a study space and a schedule, monitoring mistakes, and evaluating task success, and evaluating the success of any type of learning strategy for managing the learning process overall.

Memory-related strategies help learners link one L2 item or concept with another but do not necessarily involve deep understanding. Various memory-related strategies enable learners to learn and retrieve information in an orderly string e.g. acronyms, while other techniques create learning and retrieval via sounds e.g. rhyming, images e.g. a mental picture of the word itself or the meaning of the word, a combination of sounds and images e.g. the keyword method, body movement e.g., total physical response, mechanical means e.g., flashcards, or location e.g. on a page or blackboard.

Compensatory strategies involve guessing from the context in listening and reading, using synonyms and "talking around" the missing word to aid speaking and writing, using gestures or pause words.

Affective strategies include identifying one's mood and anxiety level, talking about feelings, rewarding oneself for good performance and using deep breathing or positive self-talk.

Social strategies are composed of asking questions to get verification, asking for clarification of a confusing point, asking for help in doing a language task, talking with a native speaking conversation partner, and exploring cultural and social norms. 
In conclusion language learning strategies can be divided into 2 types; direct language learning strategies and indirect language learning strategies. The difference between these 2 types is that direct language learning strategies enable the learner to manipulate the language directly which is opposite to indirect language learning strategies. Hence direct language learning strategies include cognitive strategies, memoryrelated strategies and compensational strategies while metacognitive strategies, affective strategies and social strategies are indirect language learning strategies. Oxford's taxonomy of language learning strategies from an article named; Language Learning Styles and Strategies: an Overview by Rebecca L. Oxford is used as the teaching materials for the students to gain the knowledge of language learning strategies in this study.

\subsection{Strategy Inventory for Language Learning Version 7.0}

Strategy Inventory for Language Learning (SILL) Version 7.0 was written for students in a second or foreign language by Rebecca Oxford in 1989. The original SILL by Oxford are made up of Background and 50 items of questions. Park Bun-seon, Kwon Mi-jeong and Hwang Jung-hwa in 1998 adapted SILL by adding 2 main components; Worksheet for Answering and Scoring the SILL and Profile of Results. See Appendix 1 These components are very useful for the student to find out by oneself on how often she or he uses language learning strategies. That means she or he realizes whether she or he always or almost always used, usually used, sometimes used, generally not used, and never or almost never used the language learning strategies.

\subsection{Definition of Cooperative Learning}

Cloud (2014) states that Johnson and Johnson in 1999 defined cooperative learning as a teaching practice that breaks students into groups of 3-4 with each student having a particular role within the group. Cooperative learning is not just group work; but a very dynamic teaching strategy that is not as simple as it may seem. It is the instructional use of small groups so that students work together to maximize their own and each other's learning.

Johnson and Johnson (2013) describe five basic elements of cooperative learning. The first element is positive interdependence. Students in cooperative learning must believe that one cannot succeed unless the other members of the group succeed and vice versa. Then they must work together to gain their success. The second element is face-to-face interaction.

Students are expected to orally explain, discuss or suggest each other. The third element is individual account ability. Personal responsibility can achieve the group's goals. The fourth element is social skills. Groups can function effectively if students have and use the social skills of leadership, decision-making, trustbuilding, communication, and conflict-management skills. The fifth element is group processing focusing on group maintenance. That is something each member did that was helpful for the group and something each member could do to make the group better in the future.

\subsection{Types of Cooperative Learning}

There are 3 types of cooperative learning named formal cooperative learning groups, informal cooperative learning groups and cooperative base groups (Johnson \& Johnson, 2013). The difference is that formal learning is a type of group work structured in assigned groups of 3-4 students in which the teacher has already analysed and assessed individuals to create the most effective group based on social dynamics within the group. Groups should be made based on a mixture of intellectual ability, academic interest and style. Informal groups are made in class and can last from a few minutes to one class period. Base groups are created early on in a group of students to help foster relationships over time and can last for years.

\subsection{The importance of Cooperative Learning}

Wang (2009) refers to Slavin in 1978 who mentioned that cooperative learning can stimulate students' interaction as well as McCaffery in 2006 who revealed that cooperative learning can promote students' motivation in learning. Wang identifies that cooperative learning can encourage students to interact, help and share each other as the relationship to positive interdependence. Wang also mentions to Vygotsky who stated that teachers should provide more opportunities for students to interact with the more-able peers. Without cooperative activities to give such learning environment, students will not grow intellectually. Thus, cooperative learning can be as the major principle in student's centred approach.

\section{Research Methodology}

This investigation is an action classroom-based research. It was conducted in the researcher's classroom so as to encourage the students to gain the knowledge of language learning strategies through their interaction, exchanging information or ideas, brainstorming in the cooperative learning activity.

\subsection{Participants}

There were 79 undergraduate students in this study. These students minor in Linguistic Program. They are from various majors; English, Thai, French, Psychology, Philosophy, History and Finance. 


\subsection{Research Instruments}

3.2.1. Strategy Inventory for Language Learning (SILL) Version 7.0 by Rebecca (1998).

3.2.2. Questionnaire: asking for the students' opinions towards the learning process of cooperative learning.

\subsection{Research Procedure}

\subsubsection{Stage 1: Warm Up Activity}

Although reading an English academic article is very difficult for Thai bachelor degree students who do not major in English Language, the researcher considers that an article named: Language Learning Styles and Strategies: an Overview by Rebecca L. Oxford is useful for the students. Then the researcher as an instructor asked the students to try reading this article in advance. They could find out the meaning of the unknown vocabularies before doing the activity in the classroom.

The warm up activity started when I introduced the students with the major concepts of language learning strategies on the topics of what they are, how importance they are and elicitation the students' own language learning strategies when they learn L1 and L2.

\subsubsection{Stage 2: Students' Process of Cooperative Learning}

1) Jigsaw reading technique was conducted with small groups of 3-4 students. Each group was assigned to study and comprehend the passages from the article; Language Learning Styles and Strategies: an Overview by Oxford. The students were encouraged to help each other understand the passages. They were also asked to brainstorm more if they used to handle any language learning strategies i.e. how they used it/them and how it/they helped her/him in learning L2. One of the students in each group was asked to be the group secretary who noted down all information her or his friends brainstormed. During this stage the researcher acted as a facilitator or a coach to assist the students if they did not understand at any point of the article. After each group finished reading and brainstorming the representatives presented the content jigsaw in sequence in front of the class room. The researcher asked questions so as to stimulate the students to discuss or criticize the points from the article more. Finally, the students were asked to complete the gap fill exercise designed by the researcher as their homework. Therefore, they had to review and find out the answers from the article and the other hand outs in Thai version again. Moreover, the researcher asked the student to analyse her or his problems in learning English and if she or he wants to improve her or his learning, which type of Oxford's Taxonomy of language learning strategies can assist her or him.

2) Jigsaw reading technique and small groups work were also handled with the content of Strategy Inventory for Language Learning (SILL) version 7.0 by Rebecca (1998). The students were asked to comprehend the questionnaire components: Background, Directions of doing the questionnaire, Worksheet for Answering and Scoring the SILL, and Profile of Results. The students in each group were asked to read and understand the questionnaire together. The researcher acted as a facilitator to explain any points if the students had questions. One of the students in each group was assigned to be the presenter to present the content jigsaw in sequence in front of the class room. The researcher asked questions so as to encourage the students to discuss or criticize the points from the questionnaire.

3) Each student was asked to complete SILL and do Worksheet for Answering and Scoring the SILL. The student had to add the scores from Part A-F. Then the score was divided by the numbers of each part to examine the score. After that the students were asked to complete the part of Profile of Results. From this stage the students knew how often they used the strategies.

4) The researcher asked each student to list 5 most language learning strategies she or he used. Then all students were asked to walk around so as to share thier language learning strategies they used most.

5) Finally, the researcher and the students concluded the language learning strategies that the students practically used on the board.

\subsubsection{Stage3: Research Data Collection}

The students were asked to complete the questionnaire asking for their opinions towards the learning process of cooperative learning.

\subsubsection{Stage 4: Data Analysis}

Data were analyzed in percentage.

\section{Results of the Study}

\subsection{The Students' Average Use of Language Learning Strategies}

It was found out that $49 \%, 47 \%$ and $4 \%$ of the students sometimes used language learning strategies, usually used language learning strategies and generally not used language learning strategies respectively. 


\subsection{The students' Opinions towards the Learning Process of Cooperative Learning}

Table-1. The Students' Opinions towards Cooperative Learning.

\begin{tabular}{|c|c|c|c|c|c|}
\hline & $\begin{array}{l}\text { Most } \\
(\%)\end{array}$ & $\begin{array}{l}\text { Much } \\
(\%)\end{array}$ & $\begin{array}{l}\text { Medium } \\
(\%)\end{array}$ & $\begin{array}{l}\text { Little } \\
(\%)\end{array}$ & $\begin{array}{l}\text { Least } \\
(\%)\end{array}$ \\
\hline 1. Teaching activities encourage you to be active in learning. & 22.78 & 54.44 & 22.78 & - & - \\
\hline $\begin{array}{l}\text { 2. Teaching activities encourage you to be interested in } \\
\text { learning. }\end{array}$ & 27.85 & 51.90 & 20.25 & - & - \\
\hline $\begin{array}{l}\text { 3. Teaching activities encourage you to pay more attention in } \\
\text { learning. }\end{array}$ & 26.58 & 49.37 & 24.05 & - & - \\
\hline $\begin{array}{l}\text { 4. Teaching activities encourage you to find out an additional } \\
\text { knowledge. }\end{array}$ & 35.44 & 49.37 & 15.19 & - & - \\
\hline $\begin{array}{l}\text { 5. Teaching activities encourage you to comprehend the } \\
\text { learning strategies that you will apply to use them in the } \\
\text { future. }\end{array}$ & 54.43 & 35.44 & 10.13 & - & - \\
\hline $\begin{array}{l}\text { 6. Teaching activities encourage you to comprehend the } \\
\text { learning strategies more easily. }\end{array}$ & 36.71 & 45.57 & 17.72 & - & - \\
\hline 7. Teaching activities encourage you to think critically. & 31.65 & 41.77 & 26.58 & - & - \\
\hline $\begin{array}{l}\text { 8. Teaching activities encourage you to ask questions in order } \\
\text { to get answers. }\end{array}$ & 29.11 & 40.51 & 27.85 & 2.53 & - \\
\hline $\begin{array}{l}\text { 9. Teaching activities encourage you to exchange ideas with } \\
\text { your friends. }\end{array}$ & 36.71 & 36.71 & 26.58 & - & - \\
\hline $\begin{array}{l}\text { 10. Teaching activities encourage you to gain self- confidence } \\
\text { for exchanging information with your friends. }\end{array}$ & 30.38 & 43.04 & 21.52 & 5.06 & - \\
\hline 11. You enjoy learning with your friends. & 37.97 & 44.30 & 16.46 & 1.27 & \\
\hline $\begin{array}{l}\text { 12. You enjoy learning the topic of language learning strategies } \\
\text { happily. }\end{array}$ & 39.24 & 45.57 & 15.19 & - & - \\
\hline 13. You feel relaxed or no anxiety in this class. & 34.18 & 32.91 & 31.65 & 1.27 & - \\
\hline 14. You are satisfied with the learning activities. & 29.11 & 51.90 & 17.72 & - & - \\
\hline $\begin{array}{l}\text { 15. You enjoy the learning atmosphere of exchanging ideas or } \\
\text { information with your friends. }\end{array}$ & 29.11 & 55.70 & 15.19 & - & - \\
\hline 16. You participate in the learning activities. & 30.38 & 56.96 & 11.39 & 1.27 & \\
\hline $\begin{array}{l}\text { 17. You consider that your ideas/information is valuable for } \\
\text { your friends. }\end{array}$ & 24.05 & 55.70 & 20.25 & - & - \\
\hline $\begin{array}{l}\text { 18. You consider that your friends' ideas/information is } \\
\text { valuable for you. }\end{array}$ & 34.18 & 54.43 & 11.39 & - & - \\
\hline $\begin{array}{l}\text { 19. Exchanging the experiences of language learning strategies } \\
\text { among you (the students) encourage you to gain more good } \\
\text { strategies in learning languages. }\end{array}$ & 43.04 & 43.04 & 13.92 & - & - \\
\hline $\begin{array}{l}\text { 20. You think that cooperative learning is an appropriate } \\
\text { technique for undergraduate students. }\end{array}$ & 41.77 & 45.57 & 12.66 & - & - \\
\hline
\end{tabular}

From the data gained it can be identified the main points as follows:

The students show their opinions in the Most scale with high percentage ( $40 \%$ up) in the following topics:

- Teaching activities encourage them to comprehend the learning strategies that they will apply to use them in the future.

- Exchanging the experiences of language learning strategies among the students encourage them to gain more good strategies in learning languages.

- They think that cooperative learning is an appropriate technique for undergraduate students.

The students shows their opinions the Much scale with high percentage ( $40 \% \mathrm{up}$ ) in the following topics:

- They participate in the learning activities.

- They enjoy the learning atmosphere of exchanging ideas or information with their friends.

- They consider that their ideas or information is valuable for their friends.

- They consider that their friends' ideas or information is valuable for them.

- They consider that their friends' ideas/information is valuable for them.

- They are satisfied with the learning activities.

- Teaching activities encourage them to be active in learning.

- Teaching activities encourage them to be interested in learning.

- They enjoy learning the topic of language learning strategies.

- They enjoy learning with their friends. 
- Teaching activities encourage them to pay more attention in learning.

- Teaching activities encourage them to find out an additional knowledge.

- Teaching activities encourage them to comprehend the learning strategies more easily.

- Teaching activities encourage them to gain self- confidence for exchanging ideas with their friends.

- Teaching activities encourage them to think critically.

- Teaching activities encourage them to ask questions in order to get answers.

- Exchanging the experiences of language learning strategies the students encourage them to gain more good strategies in learning languages.

- They think that cooperative learning is an appropriate technique for undergraduate students.

From the data gained, if the scale Most and Much are added, it is interesting to interpret the following results:

- $90 \%$ of the students agree that teaching activities encourage them to comprehend the learning strategies that they will apply to use them in the future.

- $88 \%$ of the students say that their friends' ideas or information is valuable for them and $80 \%$ of them think that their ideas or information is valuable for their friends.

- $87 \%$ of the students reveal that cooperative learning is an appropriate technique for undergraduate students and it makes them participate in the learning activities.

- $86 \%$ of the students point out that exchanging the experiences of language learning strategies among the students encourage them to gain more good strategies in learning languages.

- $85 \%$ of the students mention that teaching activities encourage them to find out an additional knowledge, they enjoy learning the topic of language learning strategies and they enjoy the learning atmosphere of exchanging ideas or information with their friends.

- $82 \%$ of the students say that teaching activities encourage them to comprehend the learning strategies more easily and they enjoy learning with their friends.

$-81 \%$ of the students point out that they are satisfied with the learning activities.

$-80 \%$ of the students agree that teaching activities encourage them to be interested in learning.

\section{Discussion}

\subsection{Cooperative Learning Should be Done in the Class Room}

There are many reasons to support that cooperative learning should be done in the class room. Various evidences from this research identify the advantages of cooperative learning as listed.

- Cooperative Learning encourage an active learning. The students show positive opinions towards cooperative learning. They think that cooperative learning is an appropriate technique for undergraduate students. They can comprehend the knowledge or input more easily. Cooperative learning stimulates them to be active in learning. They are interested in learning and they gain more good strategies in learning languages from friends that they will apply to use in the future. It also stimulates them to find out an additional knowledge and to participate more in group working.

- In the psychological aspect cooperative learning increases the students' happiness. The students said that they enjoy learning the topic of language learning strategies through cooperative learning. They appreciate the atmosphere of exchanging ideas or information with friends. They gain self- confidence for exchanging ideas or information with friends.

- Cooperative learning deals with social life skill. The students get benefits from sharing. They consider that their friends' ideas or information is valuable and their ideas or information is valuable for friends too.

All advantages of cooperative learning from this study can prove what Slavin in 1978, McCaffery in 2006 and Vygotsky who proposed Social Construction about the importance of cooperative learning as mentioned in 2.6.

\subsection{How could Cooperative Learning be managed in the Class Room?}

Freeman and Anderson (2011) state that efficient cooperative learning comes from students and teachers work together. Then the researcher realizes that the process of cooperative learning should start with the purpose of the lesson. If the content of the lesson is relevant to the students' need, the students will see the benefits of what they learn clearly. In this study the ultimate purpose is encouraging the students to gain knowledge of language learning strategies which they can apply to use in their L2 learning.

Another thing is teaching materials. They should be appropriate to students' ability. Since language learning styles and strategies is one of the topics in Language Acquisition course, the researcher chooses Language Learning Styles and Strategies: an Overview by Rebecca L. Oxford as the content input. Moreover, the students have to understand Strategy Inventory for Language Learning (SILL) version 7.0 by Rebecca Oxford adapted by Bun-seon, Mi-jeong, and Jung-hwa (1998). These 2 contents are used as the teaching materials.

The teaching stages should be taken into consideration. They should be planned in a proper sequence. In this investigation the students were asked to read the inputs as their homework. After that they were asked to do the jigsaw reading in small groups of 3-4 students. They had to help each other because each group had to do the presentation activity. 
Teachers should clearly understand that cooperative learning provides the opportunities for students to learn something together. They have to exchange ideas or information. They will learn something from peers. In this study the student had to listen what their friends' language learning strategies were. This will be useful for her or him. For she or he can try those strategies in the future. Vygotsky in 1978 points out that zone of proximal development which is the zone when a person can do on his or her own and what the person can achieve while working in cooperation can develop whenever a person works with more able individuals or more capable peers.

Teacher's roles should be taken into consideration. Although during the stages of the cooperative learning teacher's roles are as a manager or facilitator who chooses the teaching materials and designs the teaching stages or as a coach who guides if the students have any problems, the teacher should be acted as a teacher or an instructor who teaches if the students ask for help i.e. when they do not understand some points.

\section{Conclusion}

It can be concluded that the students can get the benefits from an action class room-based research. My evidence is from the questionnaire. It is discovered that the students gain more knowledge and more ways of applying language learning strategies to use in their L2 learning. This makes them realize the value of what they learn in the class room because they can use what they learn in their real life.

\section{Acknowledgements}

The author gratefully acknowledges Faculty of Humanities, Srinakharinwirot University, Thailand for supporting the research scholarship and all 79 undergraduate students who are the participants in this study.

\section{References}

Bun-seon, P., Mi-jeong, K., \& Jung-hwa, H. (1998). Strategy inventory for language learning (SILL) version 7.0 by Rebecca L. Oxford. Korean version prepared by Park Bun-seon, Kwon Mi-jeong, Hwang Jung-hwa. Retrieved from https://nanopdf.com/download/version-for-speakers-of-other-languages-learning_pdf.

Cloud, T. (2014). Cooperative learning in the classroom. Journal on Best Teaching Practices, 1(2), 7-8.

Freeman, L. D., \& Anderson, M. (2011). Technique \& principles in language teaching. UK: Oxford University Press.

Hardan, A. A. (2013). Language learning strategies: A general overview. Procedia-Social and Behavioral Sciences, 106, 17121726.

Johnson, D. W., \& Johnson, R. T. (2013). The impact of cooperative, competitive, and individualistic learning environments on achievement. In J. Hattie \& E. Anderman (Eds.), International handbook of student achievement. New York: Routledge.

Loganathan, S. (2016). Language learning strategies - a reappraisal. Available from: Language_Learning_Strategies_- $A$ Reappraisal.

Oxford, R. L. (2003). Language learning styles and strategies: An overview. Retrieved from http://web.ntpu.edu.tw/ language/workshop/read2.pdf.

Rebecca, L. (1998). Oxford adapted by Park Bun-seon, Kwon Mi-jeong and Hwang Jung-hwa.

Wang, T.-P. (2009). Applying slavin's cooperative learning to a college EFL conversation class. The Journal of Human Resource and Adult Learning, 5(1), 112-120.

\section{Appendix-1.}

\section{Strategy Inventory for Language Learning (SILL)}

Version for Speakers of Other Languages Learning English Version 7.0 for students in a second or foreign language by Rebecca L. Oxford in 1989 Korean version prepared by Park Bun-seon, Kwon Mi-jeong and Hwang Jung-hwa in 1998

\section{Background}
1. Name

2. Date
3. Age 4 . Sex
6. Language you speak at home.
5. Mother tongue
7. Language you are now learning
8. How long have you been learning the language in \#7?
9. How do you rate your proficiency in the language in \#7, compared with other students in your class?

(Circle one of these options):

$$
\text { Excellent Good Fair Poor }
$$

10. How do you rate your proficiency in the language in \#7, compared with native speakers?

(Circle one of these options):

$$
\text { Excellent Good Fair }
$$

Poor

11. How important is it for you to become proficient in the language in \#7?

(Circle one of these options):

$$
\text { Very important Important Not important }
$$

12. Why do you want to learn the language in \#7? : You can $\checkmark$ more than one answer. 


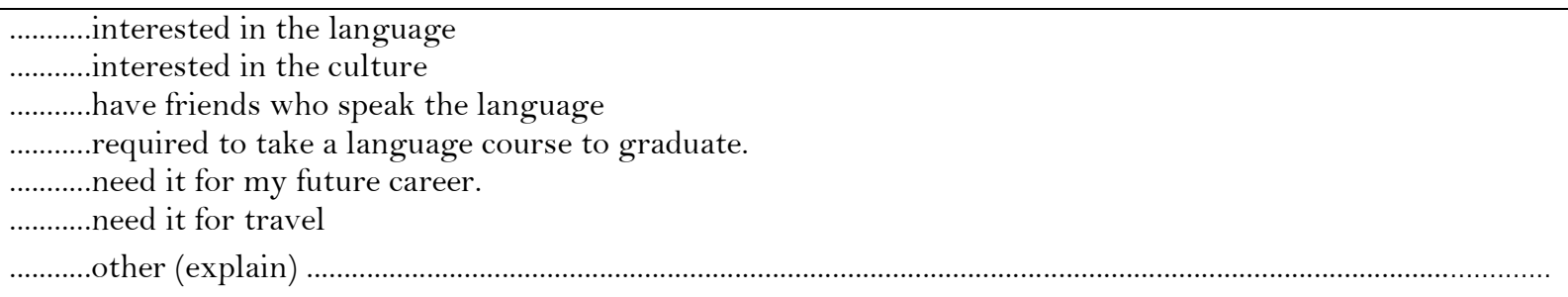

13. Do you enjoy language learning? (Circle one of these options) :

\section{Directions}

This form of the Strategy Inventory for Language Learning (SILL) is for students of English as a second or foreign language. You will find statements about learning English. On the worksheet, write the response $(1,2,3,4$, or 5$)$ that tells HOW TRUE OF YOU THE

STATEMENT IS.

1 Never or almost never true of me

2 Usually not true of me

3 Somewhat true of me

4. Usually true of me

5 Always or almost always true of me

NEVER OR ALMOST NEVER TRUE OF ME means that the statement is very rarely true of you.

USUALLY NOT TRUE OF ME means that the statement is true less than half the time.

SOMEWHAT TRUE OF ME means that the statement is true of you about half the time.

USUALLY TRUE OF ME means that the statement is true more than half the time.

ALWAYS OR ALMOST ALWAYS TRUE OF ME means that the statement is true of you almost always.

Answer in terms of how well the statement describes you. Do not answer how you think you should be, or what other people do. There are no right or wrong answers to these statements. Put your answers on the Worksheet. Please make no marks on the items. Work as quickly as you can without being careless. This usually takes about 20-30 minutes to complete. The details of each part are as follows:

Part-A 1. I think of relationships between what I already know and new things I learn in English.

2. I use new English words in a sentence so I can remember them.

3. I connect the sound of a new English word and an image or picture of the word to help remember the word.

4. I remember a new English word by making a mental picture of a situation in which the word might be used.

5. I use rhymes to remember new English words.

6. I use flashcards to remember new English words.

7. I physically act out new English words.

8. I review English lessons often.

9. I remember new English words or phrases by remembering their location on the page, on the board, or on a street sign.

Part B 10. I say or write new English words several times.

11. I try to talk like native English speakers.

12. I practice the sounds of English.

13. I use the English words I know in different ways.

14. I start conversations in English. 
15. I watch English language TV shows spoken in English or go to movies spoken in English.

16. I read for pleasure in English.

17. I write notes, messages, letters, or reports in English.

18. I first skim an English passage (read over the passage quickly) then go back and read carefully.

19. I look for words in my own language that are similar to new words in English.

20. I try to find patterns in English.

21. I find the meaning of an English word by dividing it into parts that I understand.

22. I try not to translate word-for-word.

23. I make summaries of information that I hear or read in English.

Part C 24. To understand unfamiliar English words, I make guesses.

25. When I can't think of a word during a conversation in English, I use gestures.

26. I make up new words if I do not know the right ones in English.

27. I read English without looking up every new word.

28. I try to guess what the other person will say next in English.

29. If I can't think of an English word, I use a word or phrase that means the same thing.

Part D 30. I try to find as many ways as I can to use my English.

31. I notice my English mistakes and use that information to help me do better.

32. I pay attention when someone is speaking English.

33. I try to find out how to be a better learner of English.

34. I plan my schedule so I will have enough time to study English.

35. I look for people I can talk to in English.

36. I look for opportunities to read as much as possible in English.

37. I have clear goals for improving my English skills.

38. I think about my progress in learning English

Part E 39. I try to relax whenever I feel afraid of using English.

40. I encourage myself to speak English even when I am afraid of making a mistake.

4l. I give myself a reward or treat when I do well in English.

42 I notice if I am tense or nervous when I am studying or using English.

43. I write down my feelings in a language learning diary.

44. I talk to someone else about how I feel when I am learning English.

Part F 45. If I do not understand something in English, I ask the other person to slow down or say it again. 46. I ask English speakers to correct me when I talk.

47. I practice English with other students.

48. I ask for help from English speakers.

49. I ask questions in English.

50. I try to learn about the culture of English speakers.

Worksheet for Answering and Scoring the SILL

1. The blanks (.........) are numbered for each item on the SILL.

2. Write your response to each item (write 1,2,3,4, or 5) in each of the blanks.

3. Add up each column. Put the result on the line marked SUM.

4. Divide by the number under SUM to get the average for each column. Round this average off to the nearest tenth, as in 3.4.

5. Figure out your overall average. To do this, add up all the SUMS for the different parts of the SILL. Then divide by 50 .

6. When you have finished, look at the Profile of Results. Copy your averages from the Worksheet onto the Profile.

\begin{tabular}{llllll}
\hline Part A & Part B & Part C & Part D & Part E & Part F \\
\hline Q1 & Q10 & Q24 & Q30 & Q39 & Q45 \\
Q2 & Q11 & Q25 & Q31 & Q40 & Q46 \\
Q3 & Q12 & Q26 & Q32 & Q41 & Q47 \\
Q4 & Q13 & Q27 & Q33 & Q42 & Q48 \\
Q5 & Q14 & Q28 & Q34 & Q43 & Q49 \\
Q6 & Q15 & Q29 & Q35 & Q44 & Q50 \\
Q7 & Q16 & & Q36 & & \\
Q8 & Q17 & & Q37 & & \\
Q9 & Q18 & & Q38 & & \\
& Q19 & & & & \\
\hline
\end{tabular}




\begin{tabular}{|c|c|c|c|c|c|c|}
\hline & \multicolumn{6}{|l|}{$\mathrm{Q}_{20}$} \\
\hline & \multicolumn{6}{|l|}{$\mathrm{Q}^{21}$} \\
\hline & \multicolumn{6}{|l|}{$\widetilde{Q}_{22}$} \\
\hline & \multicolumn{6}{|l|}{$\mathrm{Q}^{23}$} \\
\hline SUM Part & SUM Part & SUM Part & SUM Part & SUM Part & SUM Part & $\mathrm{A}+\mathrm{B}+\mathrm{C}+\mathrm{D}+\mathrm{E}+\mathrm{F}$ \\
\hline & & & & & & $=$ \\
\hline $\mathrm{SUM} \div 9$ & $\mathrm{SUM} \div 14$ & $\mathrm{SUM} \div 6$ & $\mathrm{SUM} \div 9$ & $\mathrm{SUM} \div 6$ & $\mathrm{SUM} \div 6$ & $\begin{array}{l}\mathrm{A}+\mathrm{B}+\mathrm{C}+\mathrm{D}+\mathrm{E}+\mathrm{F} \\
\div 5 \mathrm{O}=\end{array}$ \\
\hline (Average) & (Average) & (Average) & (Average) & (Average) & (Average) & \\
\hline
\end{tabular}

\section{Profile of Results}

This Profile shows you SILL results. These results will tell you the kinds of strategies you use in learning English. There are no right or wrong answers. To complete this profile, transfer your averages for each part of SILL and your overall average for the whole SILL. These average are found on the Worksheets, at the bottom.

\begin{tabular}{lll}
\hline Part & Which strategies are covered & Your average on this part \\
\hline A & Remembering more effectively. & \\
B & Using all your mental processes. \\
C & Compensating for missing knowledge. \\
D & Organizing and evaluating your learning. \\
E & Managing your emotions. \\
F & Learning with others. \\
\hline
\end{tabular}

Key to understanding your averages:

\begin{tabular}{lll}
\hline High & Always or almost always used. & 4.5 to 5.0 \\
\multirow{3}{*}{ Medium } & Usually used. & 3.5 to 4.4 \\
& Sometimes used. & 2.5 to 3.4 \\
Low & Generally not used. & 1.5 to 2.4 \\
\hline
\end{tabular}

The overall average tells you how often you use strategies for learning English. Each part of the SILL represents a group of learning strategies. The averages for each part of the SILL show which groups of the strategies you use most for learning English. 